\title{
The Ancient Varieties of Mountain Maize: The Inheritance of the Pointed Character and Its Effect on the Natural Drying Process
}

\author{
Stefano Sangiorgio ${ }^{1,+}{ }^{\circledR}$, Federico Colombo ${ }^{1,+}{ }^{\text {, Martina Ghidoli }}{ }^{1}$, Luca Giupponi ${ }^{2}{ }^{\oplus}$, Giulio Ferro ${ }^{1}$, \\ Carlo Giovanni Ferro ${ }^{3}$, Elena Cassani ${ }^{1}$, Michela Landoni ${ }^{4}$ and Roberto Pilu ${ }^{1, *}$
}

1 Department of Agricultural and Environmental Sciences-Production, Landscape, Agroenergy, Università degli Studi di Milano, Via G. Celoria 2, 20133 Milano, Italy; stefano.sangiorgio@unimi.it (S.S.); federico.colombo@unimi.it (F.C.); martina.ghidoli@unimi.it (M.G.); giulio_ferro@hotmail.it (G.F.); elena.cassani@unimi.it (E.C.)

2 Centre of Applied Studies for the Sustainable Management and Protection of Mountain Areas-CRC Ge.S.Di.Mont., Università degli Studi di Milano, Via Morino 8, 25048 Edolo, Italy; luca.giupponi@unimi.it

3 Department of Mechanical and Aerospace Engineering (DIMEAS) Politecnico di Torino, Corso Duca degli Abruzzi, 24, 10129 Torino, Italy; carlogiovanni.ferro@gmail.com

4 Department of Biosciences, Università degli Studi di Milano, Via Celoria 26, 20133 Milano, Italy; michela.landoni@unimi.it

* Correspondence: salvatore.pilu@unimi.it

+ Authors contributed equally to this work.

check for updates

Citation: Sangiorgio, S.; Colombo, F.; Ghidoli, M.; Giupponi, L.; Ferro, G.; Ferro, C.G.; Cassani, E.; Landoni, M.; Pilu, R. The Ancient Varieties of Mountain Maize: The Inheritance of the Pointed Character and Its Effect on the Natural Drying Process. Agronomy 2021, 11, 2295. https:/ / doi.org/10.3390/agronomy11112295

Academic Editor: Massimo Blandino

Received: 27 September 2021

Accepted: 10 November 2021

Published: 12 November 2021

Publisher's Note: MDPI stays neutral with regard to jurisdictional claims in published maps and institutional affiliations.

Copyright: (c) 2021 by the authors. Licensee MDPI, Basel, Switzerland. This article is an open access article distributed under the terms and conditions of the Creative Commons Attribution (CC BY) license (https:/ / creativecommons.org/licenses/by/ $4.0 /)$.

\begin{abstract}
The introduction of mechanized agricultural practices after the Second World War and the use of productive hybrids led to a gradual disappearance of local maize varieties. However, 13 landraces are still cultivated in North-Western Italy, in the Lombardy region; those that are cultivated in mountainous areas (roughly up to $1200 \mathrm{~m}$ in altitude) are often characterized by the pointed shape of their seeds (i.e., "Nero Spinoso", "Rostrato Rosso di Rovetta", "Spinato di Gandino" and "Scagliolo di Carenno") and the presence of pigments (i.e., "Nero Spinoso", "Rostrato Rosso di Rovetta"). The pointed shape of the seeds is an ancient characteristic of maize-ancestors, which negatively affects the yield by not allowing optimal "filling" of the ear. This study reports work on four different Italian varieties of pointed maize in order to assess the genetic bases of the "pointed character" and to try to explain the reasons for this adaptation to the mountain environment. The data obtained by genetic analysis, seed air-drying modeling and thermographic camera observations demonstrated that the "pointed trait" is controlled by the same genes across the different varieties studied and suggested that this peculiar shape has been selected in mountainous areas because it promotes faster drying of the seed, with the presence of pigments implementing this effect.
\end{abstract}

Keywords: maize; landraces; pointed maize; drying process; mountain

\section{Introduction}

The last century has been characterized by a serious loss of biodiversity, and it is estimated that about three quarters of the lines of living beings around the world (plants, animals and microorganisms) identified as being used in the past for nutrition and food production have disappeared [1]. Hence, the conservation and promotion of agrobiodiversity have been crucial topics in recent decades [2-4].

The first appearance of maize in Europe occurred after the travels of Christopher Columbus to America. After the first arrivals of samples from the Caribbean, subsequent introductions of maize germplasm from higher latitudes better adapted to European conditions boosted maize cultivation in Europe. Since then, a multitude of landraces linked to local food production and traditional farming systems have been developed [5]. 
Nowadays, northern Italy (particularly the Lombardy and Veneto regions) is one of the centers of European maize cultivation, with a harvested production of 6 million tonnes per year, used mainly as feed for livestock [6].

There is evidence that about 50 landraces of maize (mainly flint maize) were grown until 1950 in Lombardy [7]. Most of them are no longer cultivated but are still preserved in the Stezzano germplasm bank (Maize Research CREA-MAC Unit, Stezzano (BG) Italy), where about 700 traditional and ancient varieties from the peninsula are stored. As in European areas, genetic erosion in the north of Italy has reached about $90 \%$ in recent decades [8]. Despite this, the great genetic diversity found in landraces (or traditional varieties) is an essential resource for breeders and farmers [9-11]. Landraces are defined as dynamic populations of cultivated plants characterized by historical origin, distinct identity and lack of crop improvement. In addition, they are often locally adapted and associated with traditional cultivation systems $[12,13]$. Among the 13 landraces that are still cultivated in the Lombardy region, only 4 ("Nero Spinoso", "Rostrato Rosso di Rovetta", "Spinato di Gandino" and "Scagliolo di Carenno") are registered in the European Register of Conservation Varieties, a fundamental tool for the in-situ conservation of plant agrobiodiversity in Europe [14,15]. The inclusion of these landraces in the register has favored their protection and study: they are not only essential to counteract the loss of agrobiodiversity [16], but they also represent an opportunity for the creation of small agri-food chains for mountain communities [17-19] and for breeding programs [11,20].

Furthermore, several studies have highlighted that these old varieties have a high nutritional value and characteristics that make them more resistant to different abiotic and biotic factors [4,21-25]. In fact, traditional varieties are often associated with an increased accumulation of flavonoids in the pericarp. The use of maize genotypes with pigmented pericarp seems promising for a reduction in Fusarium spp. infection and fumonisin accumulation [26-29]. In addition, foods rich in flavonoids have been studied for their strong antioxidant power and for their ability to prevent chronic diseases [30-34]. In this context, landraces not only possess useful traits for plant breeding, but they have a very high nutritional value linked to their use in traditional products [13]. Among these traditional varieties, some are cultivated in mountainous areas (roughly up to $1200 \mathrm{~m}$ of altitude) and are often characterized by the pointed shape of their seeds (i.e., "Nero Spinoso", "Rostrato Rosso di Rovetta", "Spinato di Gandino" and "Scagliolo di Carenno") and their pigments (i.e., "Nero Spinoso", "Rostrato Rosso di Rovetta") [4]. The pointed shape of the seeds is an ancient characteristic of the wild ancestor of maize [35]. This characteristic negatively affects the yield since it does not allow the optimal "filling" of the ear. Despite this problem, these varieties have been selected by farmers, most likely because they were well adapted to cultivation at high altitude, compared to maize with the classic spherical/parallelepiped seed shape.

In this work, several Italian varieties of pointed maize were studied in order to assess the genetic bases of the "pointed character" and to try to explain the reasons for this adaptation to the mountain environment. These data will help the conservation of native landraces and lay the foundation of future breeding programs with the aim of obtaining new pointed varieties or new evolutionary populations.

\section{Materials and Methods}

\subsection{Plant Material}

The four pointed varieties used in this study, "Nero Spinoso", "Rostrato Rosso di Rovetta", "Spinato di Gandino" and "Scagliolo di Carenno", were obtained from the germplasm collection of CREA, Stezzano (BG). The B73 inbred line from the germplasm collection of DISAA, Milan, Italy was used to study the inheritance of the pointed trait. B73/Mo17 F1 ears were used as the non-pointed benchmark for the analysis of the shape of the kernels, the laser scan 3D digitalization, and the seed air-drying modeling. 


\subsection{Outline Analysis of the Seeds}

With the aim of comparing the seed shape of the pointed varieties with the B73/Mo17 control, we performed the outline analysis of the kernels.

The mature seeds were collected and photographed, and the images were processed to obtain the main shape of the kernels of each variety.

Further details: fifty kernels for each maize genotype were used for the elliptical Fourier descriptors analysis (outline analysis) [36]. The grains were collected from various ears of plants cultivated in the experimental field of the University of Milan, located in Landriano, Pavia, Italy. Over- or under-developed kernels of the basal and terminal parts of the ears were not considered. The kernels were photographed in dorsal view [23] using a digital camera (Canon EOS 2000D, Amstelveen, The Netherlands). The images were processed using Adobe Photoshop software. In particular, the shadows of the grains were removed, and the images were transformed into black and white. The outline coordinates were extracted with Momocs 1.3.0 [37-39] in an R environment [40] and converted into Fourier coefficients, considering 12 harmonics that gathered at least $99 \%$ of the total harmonic power [39]. The kernels were positioned in the same direction in order to control left/right asymmetry [41]; then, a landmark was defined at their base (tip cap) as a starting point for importing outline coordinates. The contours were centered, and the outline analysis was carried out without numerical normalization. Principal component analysis (PCA) was carried out on the matrix of coefficients, and the samples were plotted on the first two principal components (PCs). Linear discriminant analysis (LDA) of the principal components [42] was carried out, retaining 13 PCs. Finally, the mean shape of the kernel of each cultivar was obtained using the 'MSHAPES' function of Momocs, and multivariate analysis of variance (MANOVA) was performed to evaluate the significance of kernel shape differences between the five genotypes.

\subsection{Complementation Test and Constitution of F2 Segregating Population for Pointed Seed Trait}

A complementation test can be used to test whether two traits characterized by a similar phenotype are controlled by different genes. The two lines are crossed and, if complementation occurs, the F1 progeny will display a wild type phenotype, suggesting that the two traits are controlled by different genes.

The complementation test was performed between "Nero Spinoso", "Rostrato Rosso di Rovetta", "Spinato di Gandino" and "Scagliolo di Carenno".

All genotypes were crossed in pairwise combinations and the F1 ears were scored by visual inspection.

The F2 segregating population was obtained by crossing "Nero Spinoso" $\times$ B73/Mo17. The F1 seeds obtained were shown to obtain F2 segregating ears.

Data were recorded by visual inspection in four classes: pointed, intermediate, little pointed and not pointed. For each observation, five ears were scored.

\subsection{Seed Air-Drying Modeling}

Seed air-drying was modeled using CFD (Computational Fluid Dynamics) in order to simulate the traditional air-drying adopted by farmers in the mountainous areas of the Lombardy region. In the traditional process, maize cobs were collected, stored under farmhouse roofs and exposed to the natural air stream during autumn to dry out the grain moisture.

The aim of this analysis was to evaluate if pointed grain maize exhibited better performances during this traditional air-drying (less moisture content).

The process modeled, seed drying, aims to remove a solvent (water) through evaporation mass transfer. Evaporation is a multiphase phenomenon that requires that the solvent is present in both the liquid and gas phase. Liquid water is contained in the kernel, and water vapor is present downstream in the air. The model was set up as a mixture multiphase model. This physics approach solves a single set of governing equations for mixture and a volume fraction transport equation for each phase. The external air phase was modeled 
as a multicomponent since it contains both the vapor and the dry air. Moreover, the solid porous region (the maize grain) was modeled as a multicomponent as well (as it contains both solid dry parts and water). The interaction between the multiphase media used the Spalding Evaporation/Condensation model [43]; Sherwood and Nusselt numbers were obtained by the Armenante-Kirwan correlation.

To reduce the computational cost, the model developed was 2D; one tunnel had an air inlet and an atmospheric pressure outlet. Air entered at the inlet, evaporated the water trapped inside the porous media and exited with the vapor through the outlet. The simulation was performed using Star CCM+, a commercial software provided by SIEMENS.

Aerial data inputs were imposed to represent the typical values that would be recorded on a sunny day in autumn in the pre-Alps in the Lombardy region, where pointed maize used to be grown. These data represent the ambient boundary conditions of the process adopted widely in the Lombardy Alps, Italy, up to the middle of the 20th century. Air Temperature was set up at $15{ }^{\circ} \mathrm{C}$ with a wind speed of $0.5 \mathrm{~m} / \mathrm{s}$. The turbulence intensity and the viscosity ratio were imposed according to a standard laminar flow, respectively equal to 0.01 and 10. Kernel properties were set up according to [44]: maize density was equal to $1320 \mathrm{~kg} / \mathrm{m}^{3}$, with a specific heat of $2800 \mathrm{~J} /\left(\mathrm{kg} \cdot{ }^{\circ} \mathrm{K}\right)$, a Thermal Conductivity of $0.125 \mathrm{~W} /\left(\mathrm{m} \cdot{ }^{\circ} \mathrm{K}\right)$ and a general Porosity of $0.95 \%$.

For simplification, both kernels were simulated with the same physical properties. In this way, the differences caused by the different varieties could be neglected, and the effect of the pointed shape could be isolated.

The geometry used in the CFD simulation was obtained as follows: first of all, starting from a maize cob, a laser scan digitalized the 3D shape. After that, the image was cleaned and reconstructed with Gom software. Finally, a 2D slice of the maize kernel, both pointed and control, was obtained using spline interpolation in Solidworks CAD Software (Figure S1).

The set-up model and the mesh created are reported in Figure S2. Pictures a and b report the cross section of the air tunnel with one maize kernel in the lower side. Dry air entered at the left side of the box, stabilized and flowed around the kernel. Afterwards, air and water moisture exited from the right side of the box. Pictures $\mathrm{c}$ and d, by contrast, represent the meshed model (in which discretization was implemented by applying the finite volume method) where the fluid dynamics equations are imposed. Qualitatively, it can be seen how cells are denser downstream of the grain which captures the effect of the moisture flow dragged downstream by the surrounding air.

\subsection{The Effect of Pigmentation on the Surface Temperature of the Seeds}

Seeds were placed in the sun for about $30 \mathrm{~min}$, until they reached a constant temperature. Thermal images of "Nero Spinoso", "Rostrato Rosso di Rovetta", "Spinato di Gandino", "Scagliolo di Carenno" and B73/Mo17 (control) were taken between 11 and $12 \mathrm{~h}$ with a semiautomated long-wave infrared camera system (FLIR T650sc, FLIR Systems, Inc., Parkway Avenue Wilsonville, OR, USA). The temperature accumulated by seeds was then measured using the FLIR ResearchIR Max software.

\section{Results}

In the results below, the four traditional Italian varieties shown in Figure 1 were studied with the aim of assessing the genetic bases of the "pointed character" and to explain the reasons for the adaptation of these landraces to the mountain environment. So far as we know, this is the first work that describes the inheritance of the "pointed trait" in Italian native varieties. 


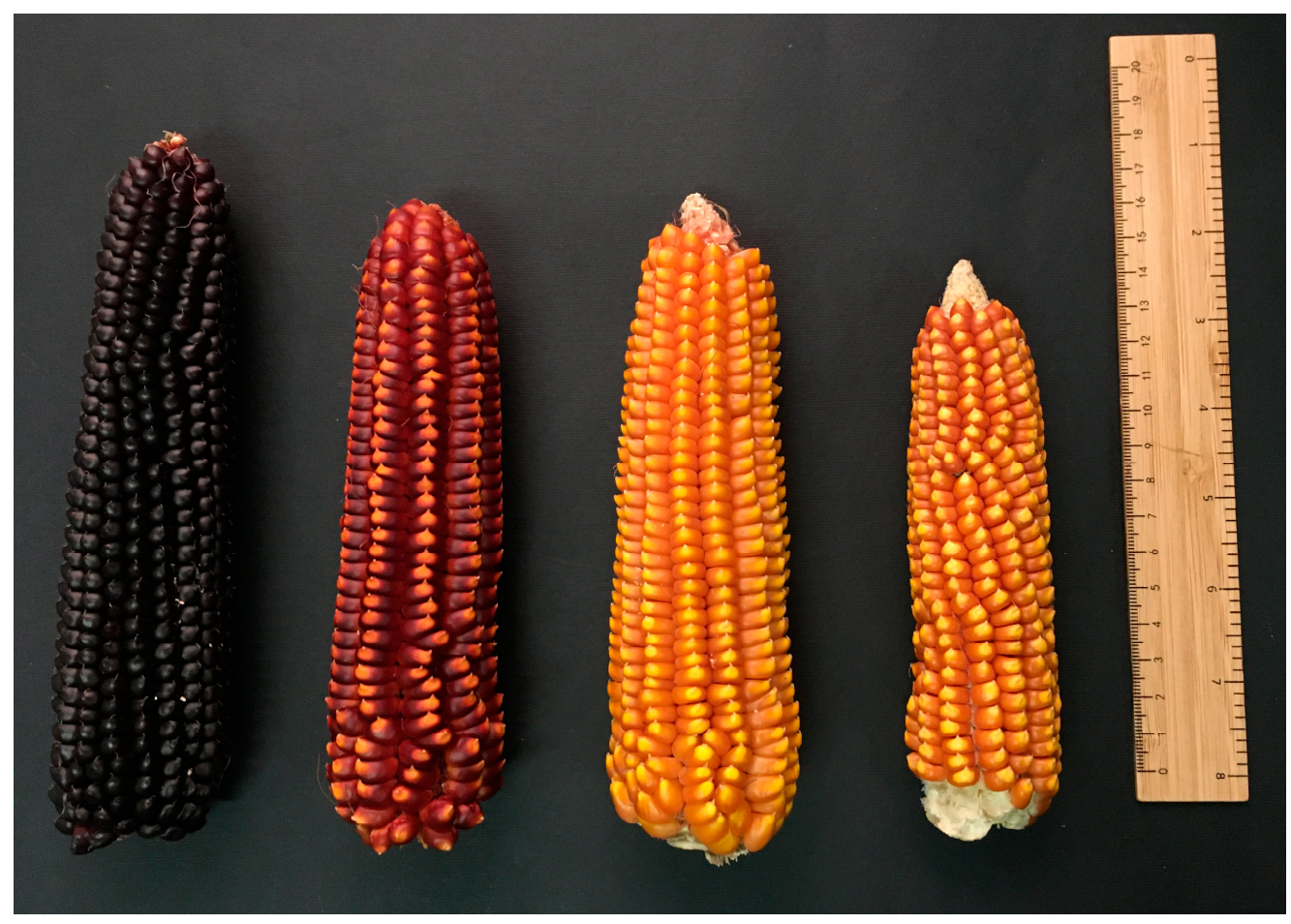

Figure 1. Four Italian maize landraces registered in the European Register of Conservation Varieties. From the left to the right: "Nero Spinoso", "Rostrato Rosso di Rovetta", "Scagliolo di Carenno" and "Spinato di Gandino".

\subsection{Shape of Kernels}

Figure 2 shows the PCA biplot of the Fourier coefficients, calculated for the grains of the five maize genotypes, the results of LDA and the mean shape of the kernels. Along the first axis (PC1) of the PCA biplot (Figure 2a), the reconstructions of the kernel shape (gray figures) become more acute at the apex. The results of the PCA and LDA of the PCs (Figure 2b) showed that B73/Mo17 (control) differs from other genotypes. While in pointed genotypes ("Nero Spinoso", "Rostrato Rosso di Rovetta", "Scagliolo di Carenno", "Spinato di Gandino") the mean shape was elliptical, in B73/Mo17 it was obovate as these grains have no beak (Figure 2c). Results of the MANOVA test confirmed significant shape differences between the kernels of the five genotypes $(F 4,245=79.45 ; p<0.01)$, and Figure 3 shows the differences between the average shape of the kernels of the control variety and that of the other genotypes. 


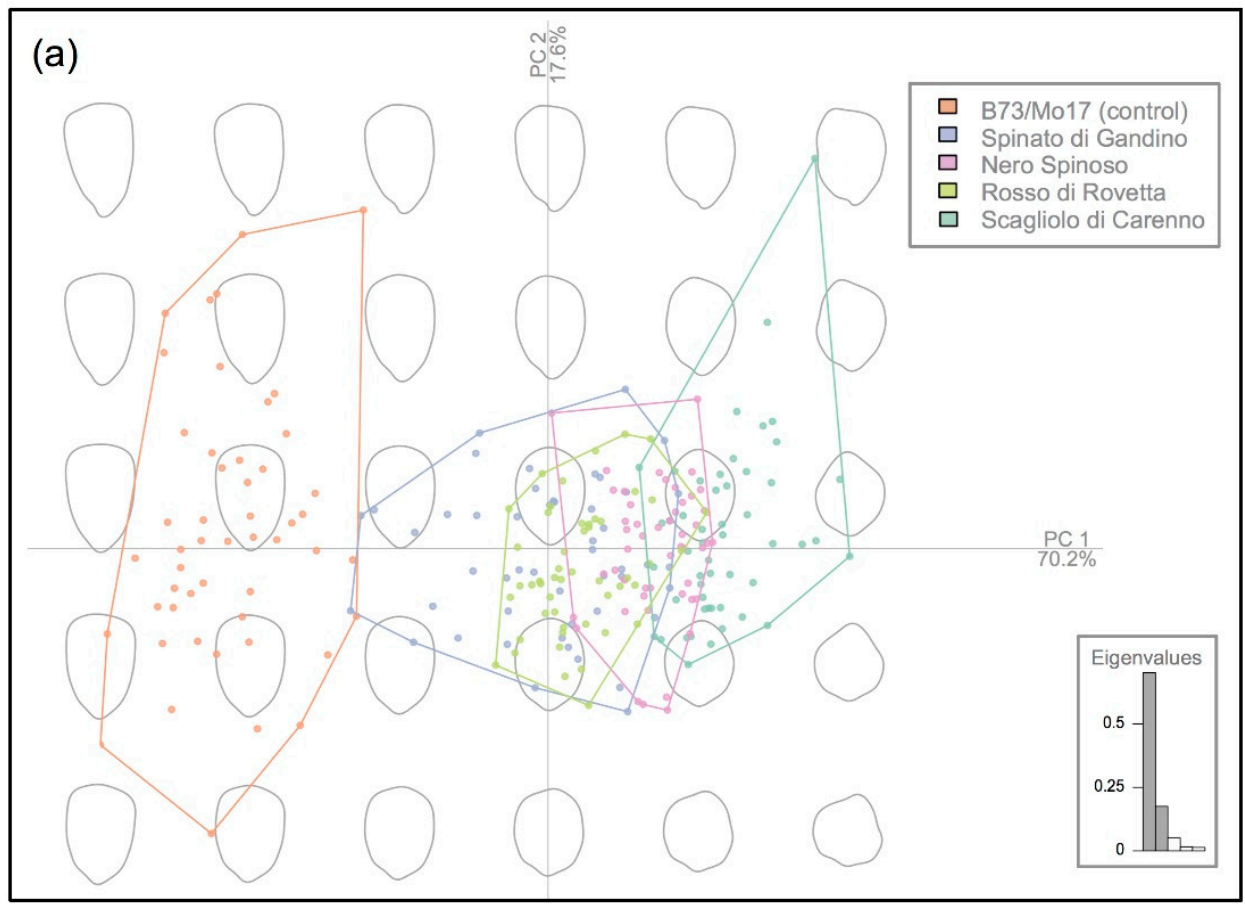

(c)
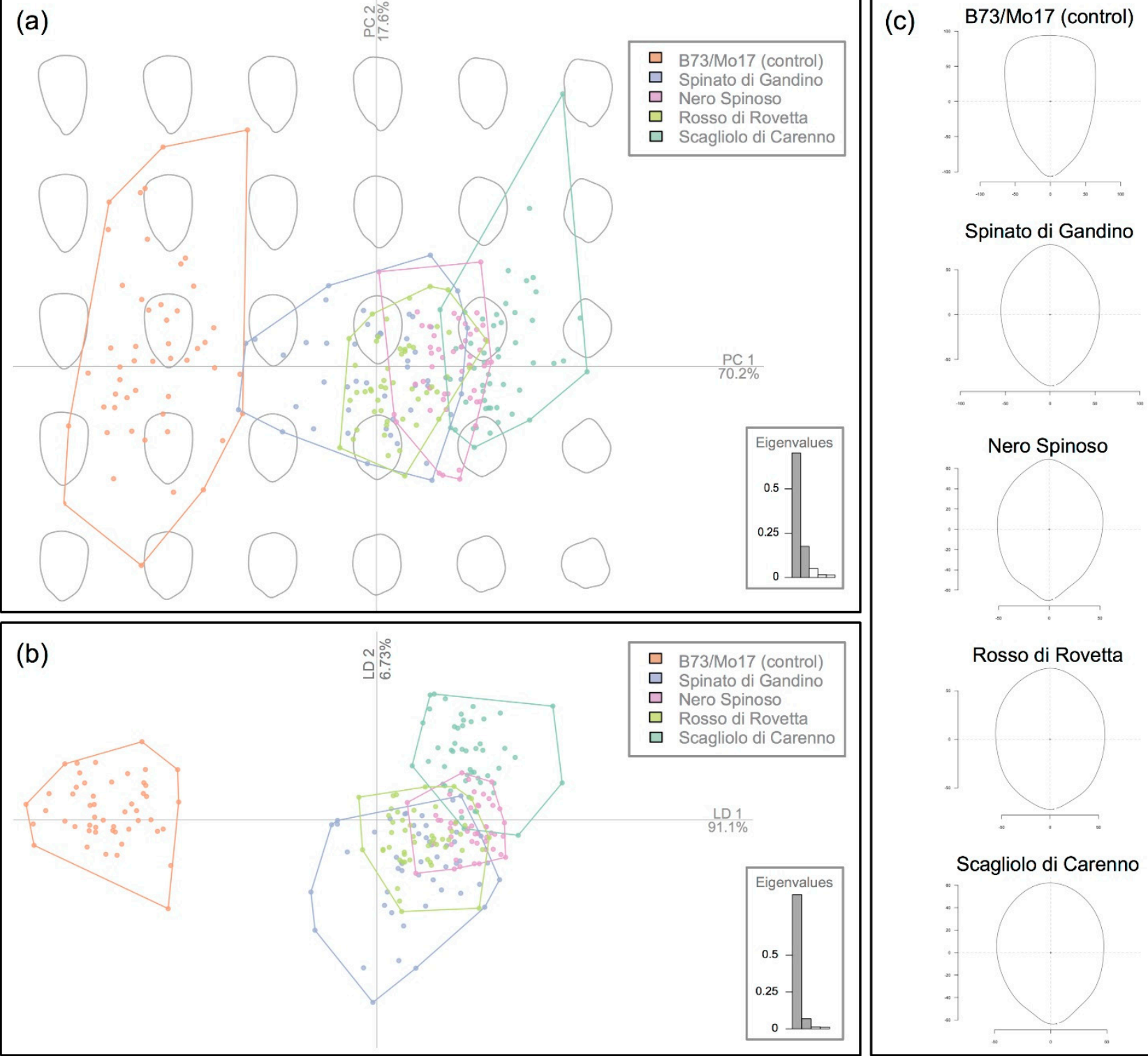

Spinato di Gandino
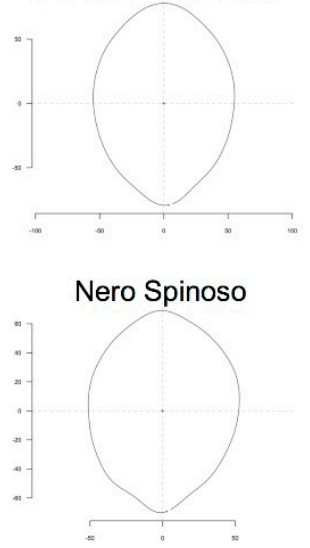

Rosso di Rovetta

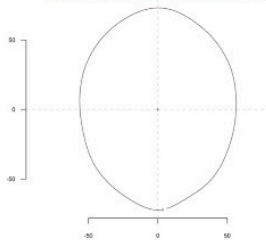

Scagliolo di Carenno

Figure 2. PCA biplot (a) resulting from outline analysis of the kernels of the five maize genotypes, LDA of PCs biplot (b) and mean shape of kernels (c), assigned according to elliptical Fourier descriptors analysis. Gray figures in the background of PCA biplot (a) show reconstructions of kernel shape according to each position in the multidimensional space. 


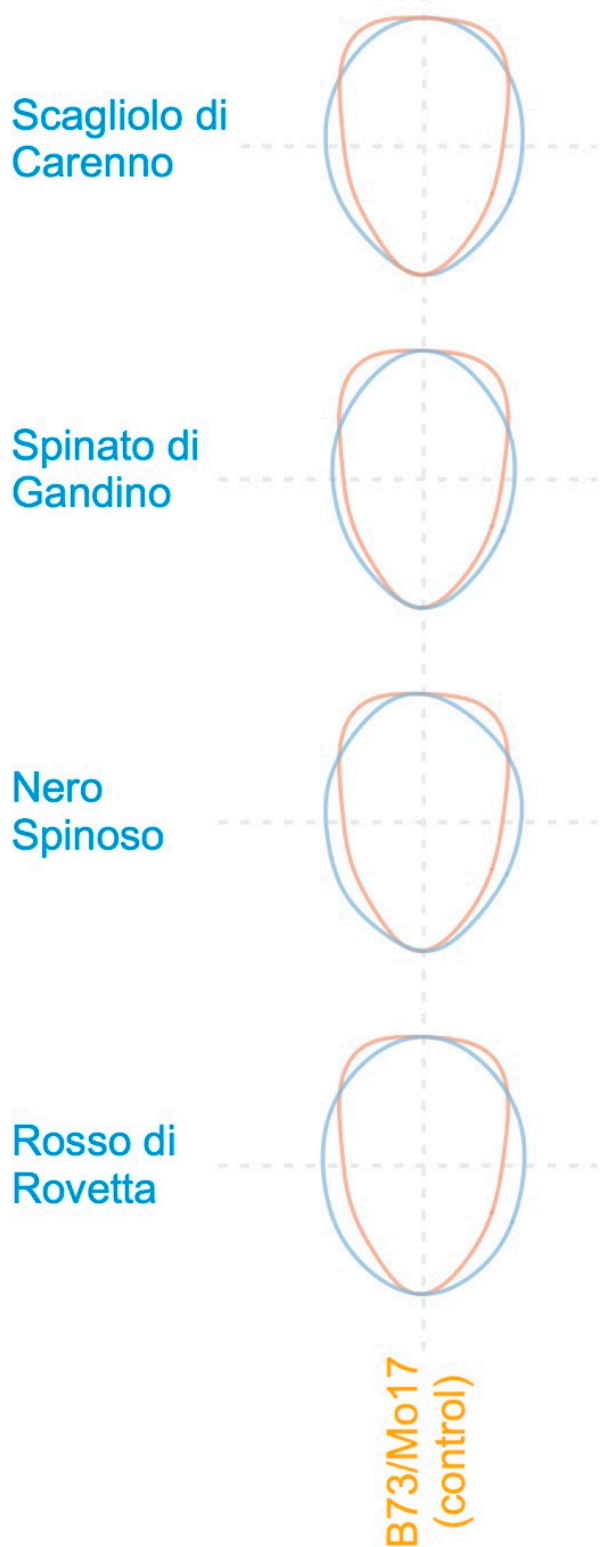

Figure 3. Comparison between the mean shape of the kernels of B73/Mo17 (control) (orange lines) and that of the other maize genotypes (blue lines).

\subsection{Inheritance of Pointed Trait}

Starting from the hypothesis that the genes involved in the "pointed trait" were common to all the pointed varieties and were due to the maternal genotype, the "Nero Spinoso", "Rostrato Rosso di Rovetta", "Spinato di Gandino" and "Scagliolo di Carenno" pointed varieties were crossed pairwise. The F1 seeds obtained from each cross were grown on to obtain F1 ears: all the ears obtained had pointed seeds, as did the following F2 ears (Figure 4), suggesting that the varieties under evaluation in this study have the same genetic basis for the "pointed trait". With the aim of estimating the number of genes involved in the "pointed trait", we studied the reappearance of the "pointed trait" in an F2 population created by crossing "Nero Spinoso" with B73/Mo17. As shown in Figure 4, F1 ears bore seeds that were slightly pointed, and, in the following F2 generation, the pointed seed trait was observed in 6 out of 183 F2 ears analyzed (Table 1). 


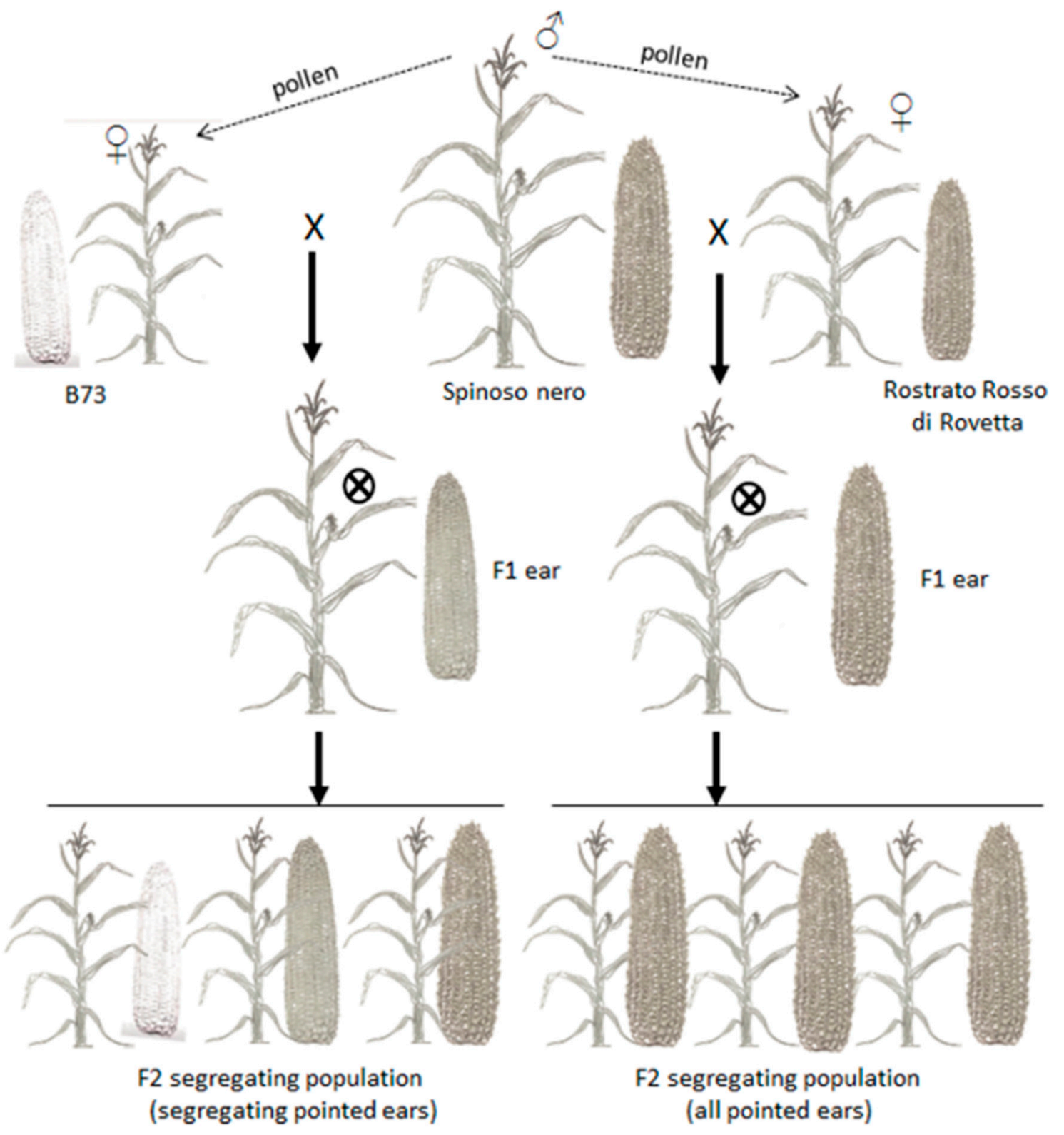

Figure 4. Inheritance of "pointed trait". On the right is shown the cross between "Nero Spinoso" and "Rostrato Rosso di Rovetta", given as an example of all the crosses carried out pairwise (complementation test) between the four pointed varieties. F1 hybrid ("Nero Spinoso" $\times$ "Rostrato Rosso di Rovetta") remains pointed as does the whole of following F2 segregating population. On the left is shown the creation of an F2 population by crossing "Nero Spinoso" with B73/Mo17. The following F2 generation segregates for the "pointed trait", permitting an estimation of the number of loci involved in this trait.

Table 1. Segregation of the trait "pointed ears" in the F2 progeny obtained by crossing "Nero Spinoso" $\times$ B73/Mo17. The hypotheses made for the $\chi^{2}$ test were 1:16 and 1:64 segregation values for "pointed ears", considering two or three major genes, respectively, involved in the "pointed trait.

\begin{tabular}{cccccccc}
\hline & Pointed & $\begin{array}{c}\text { Moderately } \\
\text { Pointed }\end{array}$ & $\begin{array}{c}\text { Slightly } \\
\text { Pointed }\end{array}$ & Not Pointed & Total & $\chi^{\mathbf{2}}(\mathbf{1 : 1 6 )}$ & $\chi^{\mathbf{2}}(\mathbf{1 : 6 4 )}$ \\
\hline nr ears & 6 & 86 & 80 & 11 & 183 & 2.76 \\
\hline \multicolumn{7}{c}{ The hypothesis is accepted if $\chi^{2} \leq 3.84$ with DF $=1}$.
\end{tabular}

The hypothesis is accepted if $\chi^{2} \leq 3.84$ with $\mathrm{DF}=1$. 


\subsection{Seed Air-Drying Modeling}

The results provided are reported graphically to assess a comparison between Nero Spinoso and the control kernels (B73/Mo17 hybrid). The velocity profile is reported in Figure 5 . The airstream at the entrance is equal to $0.5 \mathrm{~m} / \mathrm{s}$, to simulate a natural convection wind inside a farmhouse. It can be seen from the pictures that the airflow around Nero Spinoso reaches a maximum speed of $0.67 \mathrm{~m} / \mathrm{s}, 7 \%$ higher than that of the control maize. Moreover, the downstream appears more turbulent, a factor that increases the humidity exchange and transport.

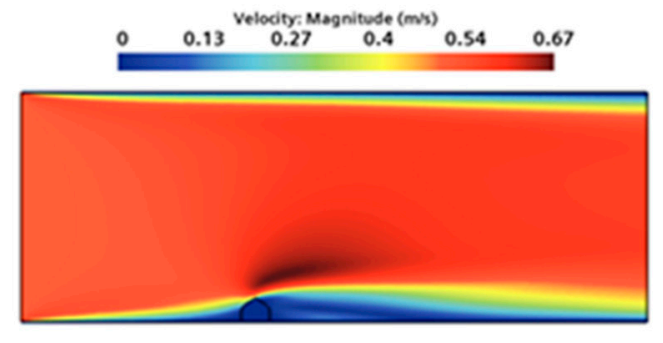

(a)

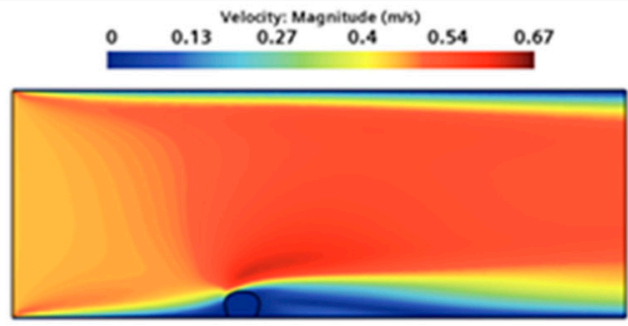

(b)

Figure 5. Velocity contour profile over a kernel extrapolated from the CFD simulation. With an airstream profile of $0.5 \mathrm{~m} / \mathrm{s}$ note, the higher speed (dark red) over the point of the kernel of spinoso maize (a) compared to the control variety (b). This higher speed increases the turbulence intensity downstream enhancing the drying process.

The second type of data extrapolated from the CFD simulation is the evaporation rate. In Figure 6, this rate is reported at different timings, i.e., $0.5 \mathrm{~s}$ for pictures a and $\mathrm{b}$ and $1 \mathrm{~s}$ for pictures $\mathrm{c}$ and $\mathrm{d}$. At the beginning, after $0.5 \mathrm{~s}$, the evaporation rate of Nero Spinoso is $15 \%$ higher than that of the control. Qualitatively, the downstream aerodynamic trail of humidity is also wider. After $1 \mathrm{~s}$, Nero Spinoso maintained the gain of $15 \%$ versus the commercial control kernel. The two behaviors are also reported graphically in Figure 7. The integral of the curve on the left is visibly larger than the one on the right.
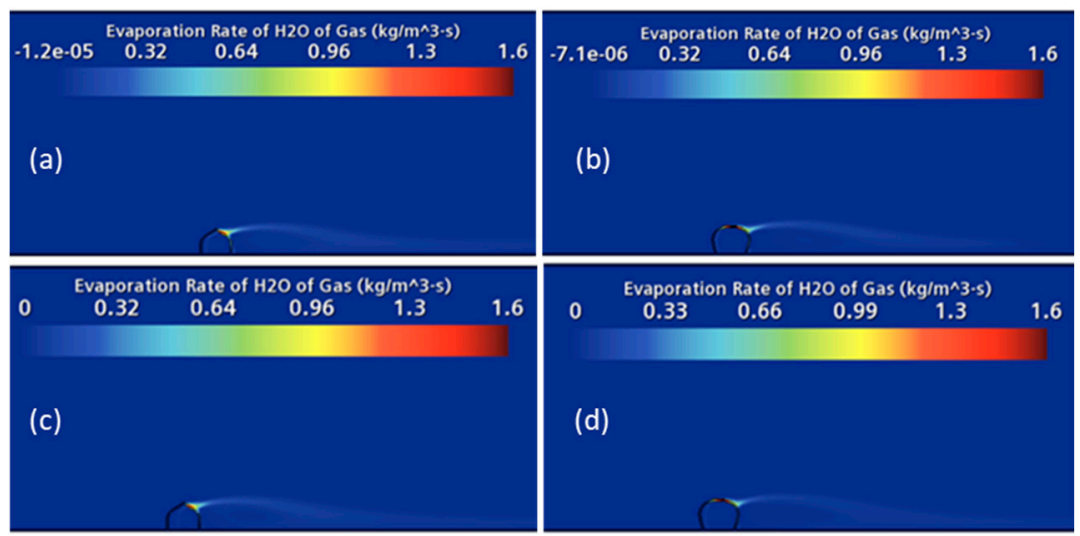

Figure 6. Evaporation Rate $\left[\frac{\mathrm{Kg}}{\mathrm{m}^{3} * \mathrm{~s}}\right]$ at different timings extrapolated from the CFD simulation. (a) Nero Spinoso at $0.5 \mathrm{~s}$; (b) control (B73/Mo17 hybrid) at $0.5 \mathrm{~s}$; (c) Nero Spinoso at $1 \mathrm{~s}$; (d) control at $1 \mathrm{~s}$. 

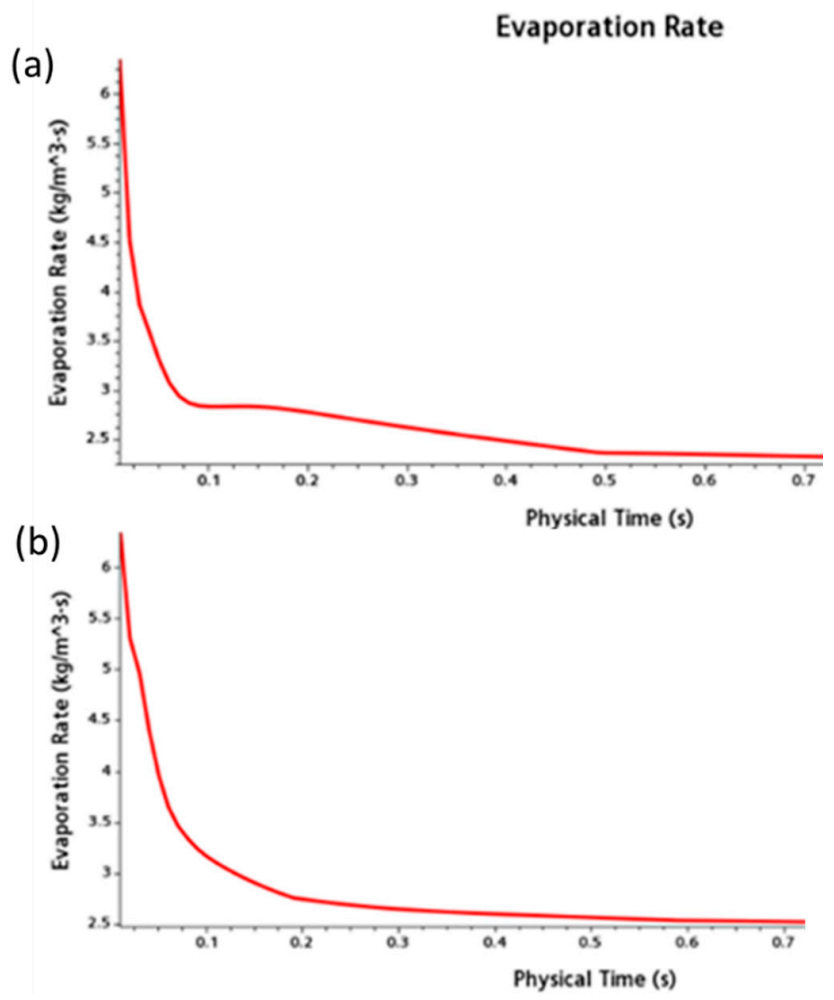

Figure 7. Evaporation rate plot vs. time extrapolated from the CFD simulation. (a) Nero Spinoso, (b) control maize (B73/Mo17 hybrid).

Finally, the last comparison is reported for the Volume Fraction of water inside the kernel after $0.5 \mathrm{~s}$ and $1 \mathrm{~s}$ of airflow. Despite the two values being very close (both the simulations start with same boundary conditions and are run for 1 s of physical time), it is the internal distribution of water that is impressive.

Nero Spinoso maize has a greater stream of humidity detaching from the trailing edge of the pointed kernel. The internal distribution, moreover, is macroscopically different between the two varieties after $1 \mathrm{~s}$. While for Nero Spinoso, almost half of the kernel does not contain any more humidity, for the control, this area (blue in Figure 8) is less than 30\%.
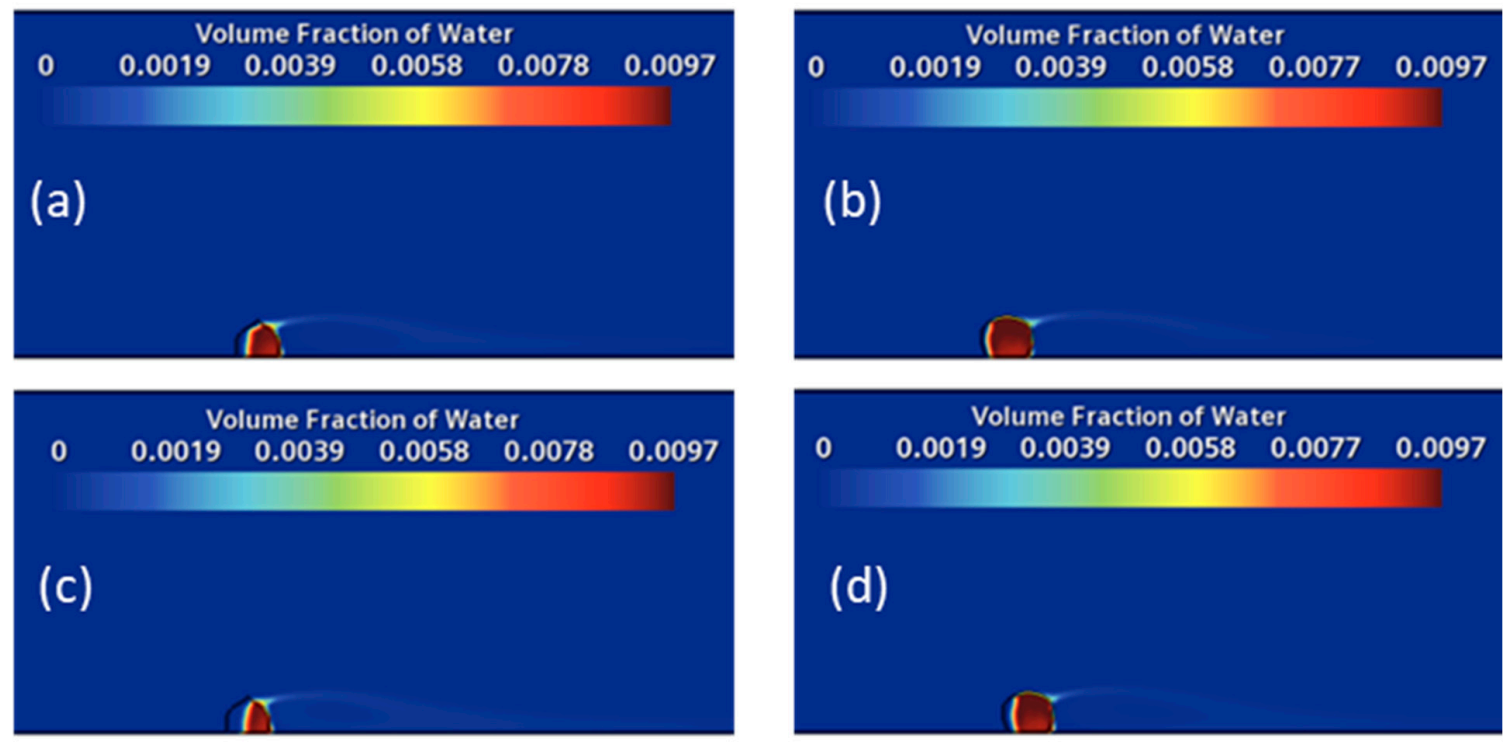

Figure 8. Volume Fraction of Water extrapolated from the CFD simulation. (a) Nero Spinoso at 0.5 s; (b) control (B73/Mo17 hybrid) at $0.5 \mathrm{~s}$; (c) Nero Spinoso at $1 \mathrm{~s}$; (d) control at $1 \mathrm{~s}$. 


\subsection{Surface Temperature of the Seeds}

Figure 9a shows representative thermal images of "Nero Spinoso", "Rostrato Rosso di Rovetta", "Spinato di Gandino", "Scagliolo di Carenno" and B73/Mo17 seeds. The temperature accumulated by seeds was then measured using FLIR ResearchIR Max software, and statistical analysis was performed (Figure 9b). Figure 9 highlights that seed temperature was higher in varieties that accumulate phlobaphenes (i.e., dark pigments): after thirty minutes of exposure to the sun, the seeds of "Nero Spinoso" reached an average temperature more than 5 degrees higher than that of the control line $\left(38.7^{\circ} \mathrm{C}\right.$ vs. $\left.33.1^{\circ} \mathrm{C}\right)$ (Figure $9 \mathrm{~b}$ ). The other three Italian landraces were in an intermediate situation, but "Rostrato Rosso di Rovetta" reached an average temperature statistically higher than "Scagliolo di Carenno" and "Spinato di Gandino", thanks to the accumulation of phlobaphenes in the pericarp. However, these two varieties accumulated one degree more than the colorless B73/Mo17 used as a control.

(a)

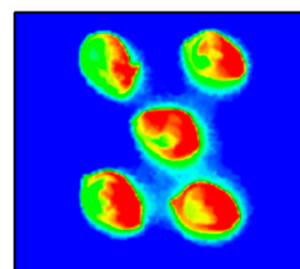

Spinoso Nero

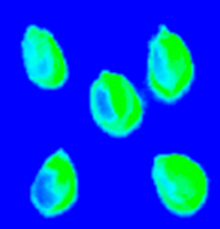

Scagliolo Carenno

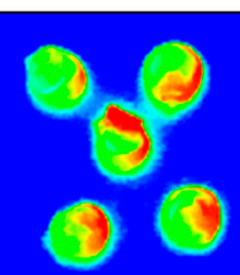

Rostrato rosso

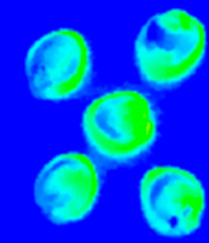

Spinato Gandino

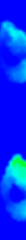

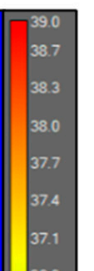

40

$2+a$

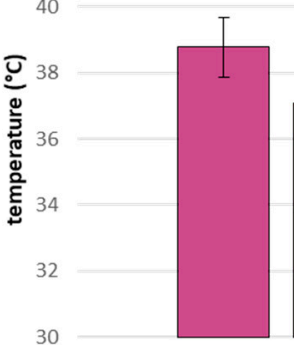

30

(b)

$\square$ Spinoso Nero $\square$ Rostrato rosso $\square$ Scagliolo Careno $\square$ Spinato Gandino $\square$ B73xMo17

Figure 9. (a) Representative image of the seed temperature acquired with the thermographic camera (FLIR T650sc). (b) Seed temperature of the Italian traditional varieties and B73/Mo17 (control). Statistical analysis was performed using ANOVA test $(p<0.05)$ and Tukey test.

\section{Discussion}

The domestication center of maize is located in Mexico, and from there it spread within the Americas and subsequently to the rest of the world, including Europe $[45,46]$. The cultivation of this crop all around the globe led to its local selection and its adaptation to new environments and, consequently, to the development of different landraces, mainly linked to local food production and traditional farming systems $[5,46]$. When compared to modern hybrids, these traditional varieties have lower yields, but are characterized by considerable phenotypic and genetic variability $[47,48]$. In addition, most of the landraces synthesize and accumulate pigments in the seed, such as phlobaphenes and carotenoids. The use of maize genotypes with pigmented pericarps seems beneficial for human health due to their antioxidant capacity [32,49-52] and seems promising for a reduction in Fusarium spp. infection and fumonisin accumulation [26-29]. The beneficial properties derived from the accumulation of phlobaphenes (and flavonoids in general) allow the landrace "Nero Spinoso" to be considered as a functional food compared to the colorless varieties [21]. 
Pointed maize, also known as beaked maize, represent a peculiarity in maize cultivation. In northern Italy, 28 pointed varieties have been surveyed, but a specific characterization has only been reported for very few of these $[21,53,54]$.

The traditional pointed varieties used in this study were "Nero Spinoso", "Rostrato Rosso di Rovetta", "Spinato di Gandino" and "Scagliolo di Carenno". Despite the lower yield, these varieties were selected because they were better adapted to cultivation in mountain areas compared to maize with the classic spherical/parallelepiped seed shape.

To our knowledge, the inheritance of the "pointed trait" has not yet been studied in the Italian landraces. Hence, starting from the hypothesis that the "pointed trait" was a quantitative character, the heritability of this trait was determined in F1 and F2 populations obtained through controlled crosses.

As shown in Figure 4, the genetic basis of this trait is common among the "Rostrato Rosso di Rovetta", "Nero Spinoso", "Spinato di Gandino" and "Scagliolo di Carenno" pointed varieties, due to the fact that the crosses carried out in all pairwise combinations showed the "pointed trait" in F1 and in the following F2 generation (Figure 4). Hence, the same loci determine the phenotype "pointed trait" in the different varieties. Furthermore, with the aim of estimating the number of genes involved in the "pointed trait", an F2 segregating population was scored for the presence of ears with pointed seeds The results obtained suggest that two/three major genes acting with additive effects are responsible for the "pointed trait" in the genetic material evaluated in the present study.

The topic of the study was to assess the quantitative effect of the pointed shape of the kernels during traditional drying. The general idea was that this shape enhances the airflow around the kernel, while it is still attached to the cob and not exposed to free air convection.

Natural or traditional solid drying was the process adopted widely in northern Italy up to the mid-20th century. Maize cobs were collected and stored under farmhouse roofs and exposed to the natural air stream during autumn and winter.

In the literature, several works related to the drying process of maize are reported. Among others, Roman et al. [55] investigated the effect of a super absorbent polymer as a desiccant. Azmir et al. [56] and Janas et al. [57], in two different research papers, evaluated the loss of humidity in maize in fluidized bed-drying. Sanghi et al. [58] used CFD to evaluate the natural convection in a solar maize dryer, while Malekjani et al. [59] collected and evaluated different simulation method for different drying processes. Regarding the simulation of the behavior of the maize kernel during artificial drying, an interesting investigation was published by Nemenyi et al. [60]. Among the literature, several works assess the drying process but none, the natural drying process specific to the northern area of Italy, where pointed kernel maize was grown.

The results presented in this work demonstrate that, for a natural drying process with a low temperature and a low airstream speed, the pointed kernel shows a distinct advantage over a variety with "conventional" shaped maize seeds, with a volume fraction of water that is $15 \%$ less with the same exposure time.

However, a parallel simulation was also run with standard parameters for the industrial drying of maize (airstream of $5-10 \mathrm{~m} / \mathrm{s}$ and air temperature around $50-60^{\circ} \mathrm{C}$ ). Within these boundary conditions the presence of the pointed shaped kernels played no role in the process (data not shown).

In further work, it is planned to simulate the drying process of the $2 \mathrm{D}$ section of the cob to understand better the interaction effect between one kernel and the next and to assess the effect of the less dense packing within the cobs of Nero Spinoso. Finally, with High Power Computing, it will be possible to analyze the entire 3D shape of the cobs scanned.

Furthermore, the pigmentation of the pericarp seems to have an effect on heat accumulation in the seeds, and this could, therefore, help to explain the use of these traditional varieties in mountain areas, where average seasonal temperatures are lower than those in the typical flat plains dedicated to maize cultivation. In fact, "Nero Spinoso" and "Rostrato Rosso di Rovetta" accumulated more heat in their seeds, thanks to the presence of 
phlobaphenes in the pericarp: $38.7^{\circ} \mathrm{C}$ and $37.0^{\circ} \mathrm{C}$, respectively (Figure 6). The difference of $1.7^{\circ} \mathrm{C}$ between these two varieties was due to the concentration of phlobaphenes: in "Nero Spinoso" these were higher compared to "Rostrato Rosso di Rovetta", as shown in Figure 1. Furthermore, the average temperature of seeds was statistically lower in the varieties that accumulate carotenoids ("Scagliolo di Carenno" and "Spinato di Gandino"), but the lowest temperature values were recorded in the colorless B73/Mo17 $\left(33.1^{\circ} \mathrm{C}\right)$ (Figure 6).

Of course, different traits are involved in adaptation to the mountainous environment: among them, earliness of and cold tolerance during heterotrophic and autotrophic growth are recognized as the most important [61,62]. Further work will be necessary to better characterize these genetic materials.

\section{Conclusions}

The data reported in this work suggest that pointed varieties have been selected in mountain areas (at least partly) for their seeds' property of drying quickly in a relatively cold and wet environment, which confers an advantage in comparison with normally shaped varieties by limiting the development of harmful fungi after harvest. Of course, other traits are involved in adaptation to mountain environments that could be useful in breeding programs with the aim of improving the sustainability of this culture. Genetic analysis pointed out that two/three genes are involved in the "pointed trait", and this information will help to preserve and improve the so far neglected OPV (open pollinated varieties).

Supplementary Materials: The following are available online at https:/ /www.mdpi.com/article/10 .3390/agronomy11112295/s1, Figure S1: Kernel acquisition process, Figure S2: Setup model.

Author Contributions: Conceptualization, R.P.; methodology, S.S. and F.C.; software, G.F., C.G.F. and L.G.; validation, M.L., E.C. and R.P.; formal analysis, S.S. and F.C.; investigation, M.G.; resources, L.G.; data curation, M.G. and M.L.; writing — original draft preparation, S.S., F.C., M.G. and L.G.; writingreview and editing, E.C. and R.P.; visualization, R.P.; supervision, R.P.; project administration, R.P.; funding acquisition, R.P. All authors have read and agreed to the published version of the manuscript.

Funding: This research was funded by Fondazione Cariplo (SOCIAAALP project), grant number 2018/2414 and partially supported by the "Montagne: Living Labs di innovazione per la transizione ecologica e digitale" project.

Institutional Review Board Statement: Not applicable.

Informed Consent Statement: Not applicable.

Data Availability Statement: Not applicable.

Acknowledgments: We wish to thank Lesley Currah for her editing and suggestions.

Conflicts of Interest: The authors declare no conflict of interest. The funders had no role in the design of the study, in the collection, analyses or interpretation of data, in the writing of the manuscript or in the decision to publish the results.

\section{References}

1. FAO. Agricultural Biodiversity. Background Paper 1. FAO/Netherlands Conference of Multifunctional Character of Agriculture and Land. 1999. Available online: http://www.fao.org/mfcal/pdf/bp_1_agb.pdf (accessed on 11 April 2019).

2. Jackson, L.; Pascual, U.; Hodgkin, T. Utilizing and conserving agrobiodiversity in agricultural landscapes. Agric. Ecosyst. Environ. 2007, 121, 196-210. [CrossRef]

3. Esquinas-Alcázar, J. Protecting crop genetic diversity for food security: Political, ethical and technical challenges. Nat. Rev. Genet. 2005, 6, 946-953. [CrossRef] [PubMed]

4. Giupponi, L.; Pilu, R.; Scarafoni, A.; Giorgi, A. Plant agro-biodiversity needs protection, study and promotion: Results of research conducted in Lombardy region (Northern Italy). Biodivers. Conserv. 2020, 29, 409-430. [CrossRef]

5. Brandolini, A. Maize introduction, evolution and diffusion in Italy. Maydica 2009, 54, $233-242$.

6. Eurostat. Eurostat Crop Production in EU Standard Humidity by NUTS 2 Regions. 2018. Available online: http://appsso. eurostat.ec.europa.eu/ (accessed on 18 June 2018). 
7. Bertolini, M. Mais in Lombardia: Varietà Tradizionali. Istituto Sperimentale per la Cerealicoltura Sezione di Bergamo, Quaderni della Ricerca. 2002. Available online: https:/ / docplayer.it/21766205-Mais-in-lombardia-varieta-tradizionali.html (accessed on 15 July 2021).

8. Hammer, K.; Xhuveli, L.; Perrino, P. Estimating genetic erosion in landraces? two case studies. Genet. Resour. Crop. Evol. 1996, 43, 329-336. [CrossRef]

9. McCouch, S.; Baute, G.J.; Bradeen, J.; Bramel, P.; Bretting, P.K.; Buckler, E.; Burke, J.M.; Charest, D.; Cloutier, S.; Cole, G.; et al. Feeding the future. Nature 2013, 499, 23-24. [CrossRef]

10. Dyer, G.A.; López-Feldman, A.; Yúnez-Naude, A.; Taylor, J.E. Genetic erosion in maize's center of origin. Proc. Natl. Acad. Sci. USA 2014, 111, 14094-14099. [CrossRef] [PubMed]

11. Puglisi, D.; Landoni, M.; Cassani, E.; Toschi, I.; Lucchini, G.; Cesari, V.; Borlini, G.; Scapin, A.; Pilu, R. Traditional farmers' varieties: A valuable source of genetic variability for biofortification programs. Maydica 2018, 63, 1-10.

12. Villa, T.C.C.; Maxted, N.; Scholten, M.; Ford-Lloyd, B. Defining and identifying crop landraces. Plant Genet. Res. 2005, 3, 373-384. [CrossRef]

13. Casañas, F.; Simó, J.; Casals, J.; Prohens, J. Toward an Evolved Concept of Landrace. Front. Plant Sci. 2017, 8, 145. [CrossRef] [PubMed]

14. Spataro, G.; Negri, V. The European seed legislation on conservation varieties: Focus, implementation, present and future impact on landrace on farm conservation. Genet. Resour. Crop. Evol. 2013, 60, 2421-2430. [CrossRef]

15. Santamaria, P.; Ronchi, L. Varietà da conservazione in Italia: Lo stato dell'arte per le specie orticole. Italus Hortus 2016, 23, 29-44.

16. Negri, V. Agro-Biodiversity Conservation in Europe: Ethical Issues. J. Agric. Environ. Ethic 2005, 18, 3-25. [CrossRef]

17. Fideghelli, C.; Engel, P. Biodiversity and local genetic resources: From knowledge to exploitation. Acta Hortic. 2009, 817, 295-310. [CrossRef]

18. Frison, E.A.; Cherfas, J.; Hodgkin, T. Agricultural Biodiversity Is Essential for a Sustainable Improvement in Food and Nutrition Security. Sustainability 2011, 3, 238-253. [CrossRef]

19. Giorgi, A.; Scheurer, T. Alpine Resources: Assets for a Promising Future-Conclusions from the ForumAlpinum 2014. Mt. Res. Dev. 2015, 35, 414-415. [CrossRef]

20. Ceccarelli, S.; Grando, S.; Maatougui, M.; Michael, M.; Slash, M.; Haghparast, R.; Rahmanian, M.; Taheri, A.; Al-Yassin, A.; Benbelkacem, A.; et al. Plant breeding and climate changes. J. Agric. Sci. 2010, 148, 627-637. [CrossRef]

21. Cassani, E.; Puglisi, D.; Cantaluppi, E.; Landoni, M.; Giupponi, L.; Giorgi, A.; Pilu, R. Genetic studies regarding the control of seed pigmentation of an ancient European pointed maize (Zea mays) rich in phlobaphenes: The "Nero Spinoso" from the Camonica valley. Genet. Resour. Crop Evol. 2017, 64, 761-773. [CrossRef]

22. Giupponi, L.; Tamburini, A.; Giorgi, A. Prospects for Broader Cultivation and Commercialization of Copafam, a Local Variety ofPhaseolus coccineusL.; in the Brescia Pre-Alps. Mt. Res. Dev. 2018, 38, 24-34. [CrossRef]

23. Giupponi, L.; Leoni, V.; Colombo, F.; Cassani, E.; Hejna, M.; Rossi, L.; Pilu, R. Characterization of "Mais delle Fiorine" (Zea mays L.) and nutritional, morphometric and genetic comparison with other maize landraces of Lombardy region (Northern Italy). Genet. Resour. Crop. Evol. 2021, 68, 2075-2091. [CrossRef]

24. Landoni, M.V.; Andrea, S.; Cassani, E.; Borlini, G.; Follador, A.R.V.; Giupponi, L.; Ghidoli, M.; Hejna, M.; Rossi, L.; Pilu, S.R. Comparison among four maize varieties in conventional and low input cultivation. Maydica 2021, 65, 1-13.

25. Landoni, M.; Puglisi, D.; Cassani, E.; Borlini, G.; Brunoldi, G.; Comaschi, C.; Pilu, R. Phlobaphenes modify pericarp thickness in maize and accumulation of the fumonisin mycotoxins. Sci. Rep. 2020, 10, 1-9. [CrossRef] [PubMed]

26. Pilu, R.; Cassani, E.; Sirizzotti, A.; Petroni, K.; Tonelli, C.; Pilu, S.R. Effect of flavonoid pigments on the accumulation of fumonisin B1 in the maize kernel. J. Appl. Genet. 2010, 52, 145-152. [CrossRef] [PubMed]

27. Sampietro, D.A.; Fauguel, C.M.; Vattuone, M.A.; Presello, D.A.; Catalan, C.A.N. Phenylpropanoids from maize pericarp: Resistance factors to kernel infection and fumonisin accumulation by Fusarium verticillioides. Eur. J. Plant Pathol. 2012, 135, 105-113. [CrossRef]

28. Venturini, G.; Toffolatti, S.; Pilu, R.; Quaglino, F.; Casati, P. First report of fusarium temperatum causing ear rot on maize in italy. Plant Pathol. 2016, 98, 677-697.

29. Venturini, G.; Babazadeh, L.; Casati, P.; Pilu, R.; Salomoni, D.; Toffolatti, S.L.; Pilu, S.R. Assessing pigmented pericarp of maize kernels as possible source of resistance to fusarium ear rot, Fusarium spp. infection and fumonisin accumulation. Int. J. Food Microbiol. 2016, 227, 56-62. [CrossRef]

30. Toufektsian, M.-C.; De Lorgeril, M.; Nagy, N.; Salen, P.; Donati, M.B.; Giordano, L.; Mock, H.-P.; Peterek, S.; Matros, A.; Petroni, K.; et al. Chronic Dietary Intake of Plant-Derived Anthocyanins Protects the Rat Heart against Ischemia-Reperfusion Injury. J. Nutr. 2008, 138, 747-752. [CrossRef]

31. Lago, C.; Landoni, M.; Cassani, E.; Doria, E.; Nielsen, E.; Pilu, R. Study and characterization of a novel functional food: Purple popcorn. Mol. Breed. 2013, 31, 575-585. [CrossRef]

32. Lago, C.; Cassani, E.; Zanzi, C.; Landoni, M.; Trovato, R.; Pilu, R.; Pilu, S.R. Development and study of a maize cultivar rich in anthocyanins: Coloured polenta, a new functional food. Plant Breed. 2014, 133, 210-217. [CrossRef]

33. Lago, C.; Landoni, M.; Cassani, E.; Cantaluppi, E.; Doria, E.; Nielsen, E.; Giorgi, A.; Pilu, R. Study and characterization of an ancient European flint white maize rich in anthocyanins: Millo Corvo from Galicia. PLoS ONE 2015, 10 , e0126521. 
34. Ginwala, R.; Bhavsar, R.; Chigbu, D.G.I.; Jain, P.; Khan, Z.K. Potential Role of Flavonoids in Treating Chronic Inflammatory Diseases with a Special Focus on the Anti-Inflammatory Activity of Apigenin. Antioxidants 2019, 8, 35. [CrossRef] [PubMed]

35. Mangelsdorf, P.C.; Reeves, R.G. The Origin of Corn: III. Modern Races, the Product of Teosinte Introgression. Bot. Mus. Leafl. Harv. Univ. 1959, 18, 389-411. [CrossRef]

36. Kuhl, F.P.; Giardina, C.R. Elliptic Fourier features of a closed contour. Comput. Graph. Image Process. 1982, 18, 236-258. [CrossRef]

37. Claude, J. Morphometrics with R; Springer: New York, NY, USA, 2008. [CrossRef]

38. Bonhomme, V.; Picq, S.; Gaucherel, C.; Claude, J. Momocs: Outline Analysis Using R. J. Stat. Softw. 2014, 56, 1-24. [CrossRef]

39. Bonhomme, V.; Forster, E.; Wallace, M.; Stillman, E.; Charles, M.; Jones, G. Identification of inter- and intra-species variation in cereal grains through geometric morphometric analysis, and its resilience under experimental charring. J. Archaeol. Sci. 2017, 86, 60-67. [CrossRef]

40. R Core Team. R: A Language and Environment for Statistical Computing; R Foundation for Statistical Computing: Vienna, Austria, 2009; Available online: http:/ / www.R-project.org (accessed on 15 July 2021).

41. Giupponi, L.; Giorgi, A. Effectiveness of modern leaf analysis tools for the morpho-ecological study of plants: The case of Primula albenensis Banfi et Ferl. Nord. J. Bot. 2019, 37, e02386.

42. Giupponi, L.; Leoni, V.; Pedrali, D.; Ceciliani, G.; Bassoli, A.; Borgonovo, G. Morphometric and phytochemical characterization and elevation effect on yield of three potato landraces of the Ligurian Apennines (Northern Italy). J. Appl. Bot. Food Qual. 2020, 93, 234-243.

43. Brewster, M.Q. Water Evaporation and Condensation in Air With Radiation: The Self-Similar Spalding Model. J. Heat Transf. 2017, 139, 081501. [CrossRef]

44. Verma, R.C.; Prasad, S. Mechanical and thermal properties of maize. J. Food Sci. Technol. 2000, 37, 500-505.

45. Matsuoka, Y.; Vigouroux, Y.; Goodman, M.M.; Sanchez, J.; Buckler, E.; Doebley, J. A single domestication for maize shown by multilocus microsatellite genotyping. Proc. Natl. Acad. Sci. USA 2002, 99, 6080-6084. [CrossRef] [PubMed]

46. Mir, C.; Zerjal, T.; Combes, V.; Dumas, F.; Madur, D.; Bedoya, C.; Dreisigacker, S.; Franco, J.; Grudloyma, P.; Hao, P.X.; et al. Out of America: Tracing the genetic footprints of the global diffusion of maize. Theor. Appl. Genet. 2013, 126, 2671-2682. [CrossRef] [PubMed]

47. Vigouroux, Y.; Glaubitz, J.C.; Matsuoka, Y.; Goodman, M.M.; Sánchez, G.J.; Doebley, J. Population structure and genetic diversity of New World maize races assessed by DNA microsatellites. Am. J. Bot. 2008, 95, 1240-1253. [CrossRef] [PubMed]

48. Warburton, M.L.; Reif, J.C.; Frisch, M.; Bohn, M.; Bedoya, C.; Xia, X.C.; Crossa, J.; Franco, J.; Hoisington, D.; Pixley, K.; et al. Genetic Diversity in CIMMYT Nontemperate Maize Germplasm: Landraces, Open Pollinated Varieties, and Inbred Lines. Crop. Sci. 2008, 48, 617-624. [CrossRef]

49. Rodríguez, V.M.; Soengas, P.; Landa, A.; Ordás, A.; Revilla, P. Effects of selection for color intensity on antioxidant capacity in maize (Zea mays L.). Euphytica 2013, 193, 339-345. [CrossRef]

50. Casas, M.; Duarte, S.; Doseff, A.I.; Grotewold, E. Flavone-rich maize: An opportunity to improve the nutritional value of an important commodity crop. Front. Plant Sci. 2014, 5. [CrossRef] [PubMed]

51. Lago, C.; Landoni, M.; Cassani, E.; Atanassiu, S.; Cantaluppi, E.; Pilu, R. Development and characterization of a coloured sweet corn line as a new functional food. Maydica 2014, 59, 191-200.

52. Petroni, K.; Pilu, R.; Tonelli, C. Anthocyanins in corn: A wealth of genes for human health. Planta 2014, 240, 901-911. [CrossRef] [PubMed]

53. Ardenghi, N.M.G.; Rossi, G.; Guzzon, F. Back to beaked: Zea mays subsp. mays Rostrata Group in northern Italy, refugia and revival of open-pollinated maize landraces in an intensive cropping system. PeerJ 2018, 6, e5123. [CrossRef] [PubMed]

54. Stagnati, L.; Martino, M.; Soffritti, G.; Lanubile, A.; Ravasio, A.; Marocco, A.; Rossi, G.; Busconi, M. Microsatellite and morphological characterization of three Rostrato di Val Chiavenna (Sondrio, Italy) maize (Zea mays L.) accessions. Genet. Resour. Crop. Evol. 2021, 68, 3025-3038. [CrossRef]

55. Román, F.; Mbuge, D.O.; Hensel, O. Modeling the effect of a superabsorbent polymer material as desiccant in maize drying using CFD. Dry. Technol. 2019, 37, 1441-1453. [CrossRef]

56. Azmir, J.; Hou, Q.; Yu, A. Discrete particle simulation of food grain drying in a fluidised bed. Powder Technol. 2018, 323, 238-249. [CrossRef]

57. Janas, S.; Boutry, S.; Malumba, P.; Elst, L.V.; Béra, F. Modelling dehydration and quality degradation of maize during fluidized-bed drying. J. Food Eng. 2010, 100, 527-534. [CrossRef]

58. Sanghi, A.; Ambrose, R.P.K.; Maier, D. CFD simulation of corn drying in a natural convection solar dryer. Dry. Technol. 2017, 36, 859-870. [CrossRef]

59. Malekjani, N.; Jafari, S.M. Simulation of food drying processes by Computational Fluid Dynamics (CFD); recent advances and approaches. Trends Food Sci. Technol. 2018, 78, 206-223. [CrossRef]

60. Neményi, M.; Czaba, I.; Kovács, A.; Jáni, T. Investigation of simultaneous heat and mass transfer within the maize kernels during drying. Comput. Electron. Agric. 2000, 26, 123-135. [CrossRef]

61. Skarbø, K.; VanderMolen, K. Maize migration: Key crop expands to higher altitudes under climate change in the Andes. Clim. Dev. 2015, 8, 245-255. [CrossRef]

62. Brandolini, A.; Landi, P.; Monfredini, G.; Tano, F. Variation among Andean races of maize for cold tolerance during heterotrophic and early autotrophic growth. Euphytica 2000, 111, 33-41. [CrossRef] 